\title{
SEARCHING FOR WAYS OF IMPROVING TEENAGERS' TOLERANCE: DETERMINATION BY MULTIETHNIC ENVIRONMENT
}

\author{
Tatiana Voronchenko' ${ }^{1}$, Nina Vinogradova ${ }^{2}$
}

\begin{abstract}
The coexistence of people of different cultures within a state, as a consequence of mass migration, has created an urgent need to identify ways to promote effective interethnic dialogue and harmonic social relationships. This study examines the problem exemplified in the multiethnic Transbaikal region of the Russian Federation, where more than one hundred nationalities cohabit. The paper illuminates the notion of tolerance, and interprets an array of sociological data to analyze the level of teenagers' tolerance in a multiethnic environment. Methods of study include a research survey, correlation analysis, and a s ystematic approach to interpreting results. Modern education systems require institutions to be competent in providing conditions for the formation of tolerance as a quality in a teenager's personality. The results of this research show that a multiethnic environment provides an effective context for a teenager to form and improve tolerance through interethnic dialogue, and that special pedagogical strategies in educational institutions could contribute to improving cultural awareness and peaceful coexistence.
\end{abstract}

UDC Classification: 37.04, DOI: http://dx.doi.org/10.12955/cbup.v4.781

Keywords: teenagers' education, teenagers' tolerance, ethnopedagogy, multiethnic environment, ethno-contact.

\section{Introduction}

The purpose of this study is to explore the way in which tolerance determines interpersonal and intergroup relationships among teenagers in educational institutions and how teenagers' tolerance develops through interethnic dialogue. The design of this study involves a sociological survey of teenagers in a multinational environment. The Transbaikal region of the Russian Federation is an example of a multinational environment where contact between multiple ethnic groups exists. In this region, more than one hundred people coexist in an area of mostly Russian people, but also indigenous (Buryat and Evenk peoples) and numerous migrants of different nationalities who arrived during various phases of history. The subjects of the sociological survey are teenagers from multinational and mono-ethnic families.

Tolerance is becoming an increasingly urgent issue for education, as well as other humanitarian studies. One of the most important tasks of modern educational institutions is to develop tolerance as a quality in a person. We agree with the position of Afdal (2005), who states "Indirectly, tolerance is educated through the development of the students' personality. Students with realistic self-esteem, high degree of self-actualization and low degree of dogmatism score high on tolerance. Education that fosters these personality traits, therefore indirectly fosters tolerance" (p. 132). The school and teenage years are the most favorable periods for the formation of such a significant quality as tolerance. Development of tolerance as an educational goal allows acquisition of positive personal elements, such as the understanding of cultural diversity, as well as different norms, beliefs, customs, and traditions.

Tolerance is the norm of a "civilized compromise" (Zolotukhin, 2003) that requires interaction of people with different tastes, attitudes, and values to overcome ethnic and national tensions and social conflicts. The sociologist Wilk-Wos (2010) writes that "an effective and constructive dialogue between people and cultures is necessary for any multicultural society to function. Intercultural communication helps to understand other cultures better, leads to wider recognition of cultural heritage, tolerance and full respect for different cultural, linguistic, ethnic and religious groups" (p. 82). Müller (2012) concedes the point that "interethnic contact is considered a potent tool for the generation of interethnic understanding and tolerance" (p. 425). Drawing on these ideas, we consider that the notions of tolerance and intercultural dialogue are tightly intertwined.

According to Walzer (1997), tolerance includes, but is not limited to, indulgence. Tolerance involves the preservation of a teenager's individual identity. It is dynamic and presupposes a spiritual openness and a position of recognition in activities. It presupposes, as Banks (2015) writes that:

\footnotetext{
${ }^{1}$ Tatiana Voronchenko, Transbaikal State University, Chita, Russian Federation, tavoronch@mail.ru

2 Nina Vinogradova, Transbaikal State University, Chita, Russian Federation
} 
To become effective citizens within their nation and the world, students need clarified and reflective cultural, national, regional, and global identities; democratic attitudes and values; and the knowledge required to function effectively within their own and other cultural groups within national and global contexts. (p. 33)

Tolerance means recognition and an understanding that a person has a right to follow different views, values, and culture. Intolerant attitudes contribute to conflicts, ethno-centrism, xenophobia, aggressive nationalism, and discrimination.

\section{Methodology}

This study draws on theories of modern educationalists concerning the special role of education and educational institutions in distributing tolerance in society (Zinov'yev, 2001; Godwin, Ausbrooks \& Martinez, 2001; McKinnon \& Castiglione, 2003; Zagorulya, 2003; Wan, 2006; Sardoč, 2010). We follow the tolerance structure of the philosopher, Glebkin (2000), who presented four components: cognitive, emotional and evaluative, axiological, and activity-based. The activity-based component is the general focus of our study as it supposes that tolerance can be achieved by a teenager's activity involving intercultural dialogue and communication at educational institutions.

A teenager's communicative tolerance can be approached by using the concept of ethnopedagogy. The educationalist Arsaliev (2013) considered the following for ethnopedagogy:

Interdisciplinary area of scientific knowledge, formed at the intersection of philosophy, pedagogy, ethnography, ethnic culture, ethnic psychology, which studies the traditional culture and pedagogy of ethnic communities in order to identify common patterns of their formation and development, opportunities of their rich educational potential in modern teaching and upbringing systems. (p. 9)

The approach of ethnopedagogy helps in comprehending the environments where contact among multiple ethnic groups exists along with communicative tolerance. Ethnopedagogical technologies are aimed at cultural adaptation of children from diverse groups, the development of interethnic dialogue, and productive communication among people of different cultures.

We consider communicative tolerance as the basic quality of a person displayed in human communication through mutual understanding, cooperation, and cultural awareness "without aggressive protecting actions" (Grebenets, 2013, p. 18). As Mambetova (2009) states, "communicative tolerance is determined by life experience and moral principles" (p. 23). We used a survey and questionnaire method and drew on the works of Fowler (2002), Kreuger and Neuman (2006), and Creswell (2013) in discussing the results of this sociological survey. A correlation analysis was used to process the information collected. A systematic approach aided the interpretation of results.

\section{Results}

Teenage years are the most critical period for developing and strengthening tolerance as a quality in a person. Further, tolerance does not develop but rather transforms with social, political, economic, and demographic conditions of a particular ethnic group. The researchers Kozlova (2010) and Kondrykinskaya (2005) argued that acquisition of culture and awareness of ethnic characteristics of the community, in the context of philosophical positions of "me and the world" and "we are in the world of other people", create a system of tolerance. In this case, the interiorization of a person's ethnic values occurs within a multiethnic environment. The ability to reflect on the external reality and the world of wide social relationships affects the formation of a teenager's inner world, optimizing his or her life in terms of specific ethnic reality (Khotinets, 2011). We share the position of Kon (1984), who regarded communication as having the highest position in forming tolerance, because it assigns certain human ideas, values, and attitudes towards reality. Both heterogeneity and homogeneity of the ethnic and cultural environment significantly affect the formation of tolerance.

Multiethnic environments influence a teenager's communicative tolerance. Multiethnic environments are environments where multiple ethnic groups interact, with families mostly from diverse cultures, and interethnic communication provides a teenager with more opportunities for interethnic understanding and tolerance. Tolerance in communication is characterized by non-aggressive behavior, positive dealings in conflicting situations, preservation of dignity, and use of speech utterances that make communication more immediate and free of charges and claims against one another. 
Voronchenko and Vinogradova (2014) organized a sociological survey to trace interethnic situations among young people in the region. It aimed to study the impact of environments of multiple ethnic groups on the formation of tolerance. It involved in the Transbaikal region (a nationally heterogeneous environment). The subjects were teenagers of 12-15 years (total sample 160), involving three groups:

- Group 1 - teenagers from multinational families in nationally heterogeneous environment (Chita city);

- Group 2 - teenagers from monoethnic families in nationally heterogeneous environment (Chita city);

- Group 3 - teenagers from monoethnic families in nationally homogeneous environment (AginBuryat district).

The questionnaire was aimed at defining the type and level of teenagers' communicative tolerance. It showed 16.0\% of teenagers from Group 1, 3.6\% from Group 2, and 7.1\% from Group 3 preferred their own ethnic group and would wait for trouble to start on the part of other nationalities, while experiencing tension and irritation in dialogue with representatives of other ethnic groups (indicating intolerance and ethno-centrism). Irrespective of the type of family and ethnic characteristics of the environment, the majority of teenagers showed a positive attitude towards other nationalities as well as their own, and respected other cultural values. However, teenagers from the multinational families in the nationally heterogeneous environment showed ethno-centrism to a greater degree than teenagers from other groups, which displayed a lower development of tolerance.

One part of the questionnaire referred to the study of interethnic tolerance. The list contained questions concerning teenagers' attitude to representatives of different nationalities. Respondents answered the question: "Do you have a dislike to people of different nationality?", with "do not have" in $77.5 \%$ of the cases. This attitude towards representatives of other nationalities indicated that teenagers regarded all person as equal in position.

Most respondents "have friends" among people of other nationalities. Answers for the question "Are there any people of other nationalities among your close friends?" included "yes, of course" in $70.8 \%$ of the cases, "no, there are not, have a dislike" in $10.0 \%$. The latter was explained by "I do not like their appearance, behavioral pattern, traits" in $9.8 \%$ of cases, while $2.0 \%$ of respondents chose "These people break the laws and norms of behavior".

The question "Are you willing to cooperate with people of other nationalities in certain situations?" queried the level of a respondent's readiness for tolerant behavior during interaction. Results showed high levels of readiness, with responses of "ready to invite them to house" in $43.7 \%$, "ready to work with them in the same group" in $52.9 \%$, "ready to spend with them spare time" in $33.6 \%$ (with a degree of restraint), and "ready to stand for them when they are unfairly criticized by people of my nationality" in $43.7 \%$ of cases.

The question: "Have you encountered cases of human humiliation caused by nationality or religion?", had the following answers: "yes, heard from friends" and "yes, saw on TV" in 42.5\%, "yes, seen it myself" in $18.3 \%$, and "no, never encountered" in $16.7 \%$ of cases. The question about cases of intolerance in modern society had the following answers: "have not encountered any cases of intolerance" in $45.8 \%$, and "have encountered cases of intolerance" in $54.2 \%$ of respondents (these included fascist symbols on leaflets, posters, and inscriptions; meetings and other public speaking events of nationalists; and direct physical violence).

In $43.1 \%$ of cases, respondents preferred dealing with conflict with "listen to the opponent's opinion and try to defuse a conflict", but at the same time $32.8 \%$ preferred to "take a strong stand and do not take the opponent's position". Thus, we see that the respondents aimed to assess the situation first, and then behave according to their individual characteristics, with most trying to be a "peacemaker" and resolve conflict. The teenagers regarded creating and implementing educational programs to develop tolerance in children and young people at the regional and federal levels (75.8\% of respondents) as necessary pursuits.

The teenagers were willing to communicate in a multicultural space, as well as understand differences in outlook. However, there were difficulties in acceptance of the different norms of behavior and communication among these teenagers. For example, the answers to the question: "What is the best 
way to bring up national tolerance towards other people?" were of special significance. An important result of the survey was that most respondents considered it essential to organize school activities so teenagers could "get to know" each other, establish a dialogue, and enhance their social network with interaction and mutual support. Some opinions of respondents implied these events would also allow schools to identify children who were in special need of additional adaptation, and therefore, could provide the necessary psychological support, of particular importance for educational psychology.

\section{Conclusions}

Multiethnic environments promote rapid and effective formation of tolerance among teenagers. Teenagers from multinational families in an environment of contact with multiple ethnic groups should be the subject of purposeful work by teachers and school psychological services. Teenagers' tolerance and protection from intolerance demand special pedagogical strategies for implementation in educational institutions. Sardoc (2010), in the book, "Toleration, Respect and Recognition in Education", provided two positions that encourage the respect of difference. We explored their proposed implementation in educational institutions in Transbaikal region, where there is intolerance among teenagers from multinational families in a nationally heterogeneous environment. According to Sardoc (2010, p. 131), 16\% of respondents had "better knowledge and understanding, but not necessarily appreciation, of the differences that exist in our society as the key to greater tolerance"; and "training and transforming the emotions of individuals when they meet those who hold differences. This has been expressed in empathy-based approaches to education for tolerance".

In respect of the first result, we assume that the more that teenagers know about the culture, experience, and customs of other nationalities, the less they show intolerance. We see special courses with regional, national, and global cultural components in educational institutions as one way to develop such a position. In regard to the second statement, as extracurricular activity provides more opportunities to influence teenagers' emotions, we consider joint participation of pupils from diverse backgrounds as the most efficient way to begin to instill empathy and involvement. We propose various types of extracurricular activity to provide such emotional transformations, including: a festival of cultures, and traditional dance, song, and national cuisine contests.

The authors conclude that a multiethnic environment improves a teenager's tolerance of other cultures; interethnic dialogue is a necessary condition for development of tolerance and harmonization within a multiethnic society; and ethnopedagogical technologies can be used in educational institutions for teenagers from both multinational and monoethnic families, and especially for those from multinational families in a nationally heterogeneous environment. In addition, communicative tolerance is a quality of a person that is peculiar to most teenagers in a multiethnic society (indicated by positive attitudes towards other nationalities and respect for other cultural values). Furthermore, pedagogical strategies aimed at reducing intolerance among teenagers could include special courses with regional, national, and global cultural components; implementing special extracurricular activities; and providing empathy and effective interethnic dialogue. Finally, development of teenagers' tolerance is an effective way to change a potentially conflicting situation into peaceful coexistence among peoples.

\section{References}

Afdal, G. (2005). Tolerance and the curriculum. Münster: Waxmann Verlag.

Arsaliev, S. M. K. (2013). Metodologiya sovremennoy etnopedagogiki [Methodology of modern ethnopedagogy]. Moscow: Gelios.

Banks, J. A. (2015). Cultural diversity and education. New York: Routledge.

Creswell, J. W. (2013). Research design: Qualitative, quantitative, and mixed methods approaches. Thousand Oaks: SAGE publications.

Fowler, F. J. (2002). Survey research methods (Applied social research methods). Thousand Oaks: SAGE publications.

Glebkin, V. V. (2000). Tolerantnost' i problema ponimaniya [Tolerance and problem of understanding]. Asmolov, A.G. (ed.). Na puti k tolerantnomu soznaniyu [On the way to tolerant conscious] (pp. 8-176). Moscow: Smysl.

Godwin, K., Ausbrooks, C., \& Martinez, V. (2001). Teaching Tolerance in Public and Private Schools. Phi Delta Kappan, no. 7. Retrieved from: http://www.questia.com/read/1G1-72007069/teaching-tolerance-in-public-and-private-schools 
Grebenets, E. S. (2013). Vospitaniye kommunikativnoy tolerantnosti kak napravleniye vneurochnoy deyatel'nosti v obshcheobrazovatel'nom uchrezhdenii [Upbringing of communicative tolerance as extracurricular activity of education institution]. Vestnik of Sholokhov Moscow State University for the Humanities, №3, pp. 17-21.

Khotinets, V. Y. (2011). Etnokul'turnyy resurs psikhicheskogo zdorov'ya detey [Ethnocultural resourse of children's mental health]. Vestnik of Nekrasov Kostroma State University, №2, pp. 232-235.

Kon, I. S. (1984). V poiskakh sebya [In search of myself]. Moscow: Politizdat.

Kondrykinskaya, L. A. (2005). S chego nachinayetsya Rodina? [From where the motherland begins]. Moscow: Sphere.

Kozlova, S. A. (2010). Ya-chelovek [I am human]. Moscow: School Press.

Kreuger, L. W., \& Neuman, W. L. (2006). Social work research methods: Qualitative and quantitative applications. Boston and New York: Pearson \& Allyn Bacon.

Mambetova, R. T. (2009). Svyaz' kommunikativnoy tolerantnosti lichnosti s individual'no-tipologicheskimi osobennostyami starshikh podrostkov [Connection between communicative tolerance of the individual with individual and typological features of teenagers]. Yaroslavl Pedagogical Bulletin, n. 60, pp. 21-23.

McKinnon, C., \& Castiglione, D. (eds.) (2003). The Culture of Toleration in Diverse Societies: Reasonable Toleration. Manchester, England: Manchester University Press. Retrieved from: http://www.questia.com/read/119036929/the-culture-oftoleration-in-diverse-societies-reasonable

Müller, F. (2012). Making contact. Generating interethnic contact for multicultural integration and tolerance in Amsterdam. Race Ethnicity and Education, 15(3), 425-440.

Sardoč, M. (ed.) (2010). Toleration, Respect and Recognition in Education. Chichester, West Sussex, UK: Wiley-Blackwell. Retrieved from: http://www.questia.com/read/123533188/toleration-respect-and-recognition-in-education

Voronchenko, T., \& Vinogradova, N. (2014). Vliyaniye etnokontaktnoy sredy na kommunikativnuyu tolerantnost' podrostkov [Ethno-contact environment's impact on teenagers' communicative tolerance]. (eds.) Prostranstvo etnosa v sovremennom mire [Ethnos space in modern world], pp. 358-364. Groznyy: Chechen State University.

Walzer, M. (1997). On toleration. New Haven, CT: Yale University Press.

Wan, G. (2006). Teaching Diversity and Tolerance in the Classroom: A Thematic Storybook Approach. Education, no. 1. Retrieved from: http://www.questia.com/read/1G1-153761697/teaching-diversity-and-tolerance-in-the-classroom

Wilk-Woś, Z. (2010). The role of intercultural dialogue in the EU policy. Journal of Intercultural Management, 2(1), 78-88.

Zagorulya, T. V. (2003). Vospitaniye patriotizma i tolerantnost' [Education of patriotism and tolerance]. Historical and Pedagogical Readings, (7), 321-323.

Zinov'yev, D. V. (2001). Formirovaniye sotsiokul'turnoy tolerantnosti kak faktor povysheniya pedagogicheskogo masterstva budushchego pedagoga [Formation of social and cultural tolerance as the factor of teacher's pedagogical skill]. Krasnoyarsk: SibSTU.

Zolotukhin, B. M. (2003). Terpimost' i tolerantnost': skhodstvo i razlichiye [Tolerance and toleration: similarities and differencies]. Vestnik of Kuzbass State Technical University. Retrieved from: http://cyberleninka.ru/article/n/terpimost-itolerantnost-shodstvo-i-razlichie 